\title{
An improved synthesis approach of the HIV-1 inhibitor RDEA427, a pyrrolo $[2,3-d]$ pyrimidine derivative
}

\author{
Boshi Huang, Xinhao Liu, Wanzhuo Li, Zihui Chen, Dongwei Kang, Peng Zhan* and \\ Xinyong Liu* \\ Department of Medicinal Chemistry, Key Laboratory of Chemical Biology (Ministry of \\ Education), School of Pharmaceutical Sciences, Shandong University, 44 West Culture Road, \\ 250012 Ji'nan, Shandong, PR China \\ E-mail: zhanpeng1982@163.com;xinyongl@sdu.edu.cn
}

DOI: https://doi.org/10.24820/ark.5550190.p009.866

\begin{abstract}
The diarylpyrimidine-like derivative RDEA427 is a highly potent inhibitor against wild-type and a wide range of drug-resistant HIV-1 strains and has attracted much attention. However, the yield of its reported synthesis is too low and the route is less environment-friendly and uneconomic. In order to achieve a short and more economic synthesis of RDEA427, an investigation was carried out. The optimized synthesis approach of RDEA427 was accomplished in an increased overall yield (39\%). Moreover, the new route is more environment-friendly and economic. This work will accelerate the drug discovery process.
\end{abstract}

Keywords: HIV-1 inhibitor, RDEA427, diarylpyrimidine-like derivative, increased overall yield, environment-friendly

\section{Introduction}

Currently, non-nucleoside reverse transcriptase inhibitors (NNRTIs) are major components of highly active antiretroviral therapy (HAART) to treat HIV-1 infections. ${ }^{1}$ However, the usage of the first generation NNRTIs has been significantly compromised by the emergence of drug-resistant HIV-1 strains. A compelling medical need still exists for novel HIV-1 NNRTIs with improved antiresistance profiles. $^{2}$

As the second generation NNRTIs, diarylpyrimidine (DAPY) derivatives exhibit remarkable potency against both the wild-type (wt) and mutant HIV-1 strains. Two DAPY-type drugs, etravirine (ETR, 2008) and rilpivirine (RPV, 2011) have been approved for clinical use ${ }^{3}$. RDEA427 (1), 4-((2-((4-cyanophenyl)amino)-7H-pyrrolo[2,3- $d$ ]pyrimidin-4-yl)oxy)-3,5dimethylbenzonitrile, is another representative DAPY-like NNRTI which was developed in a 
multidisciplinary structure-based drug design effort. RDEA427 inhibits wt and a wide range of drug-resistant HIV-1 strains at subnano- or nanomole concentrations in cell-based assays ${ }^{4,5}$ (Figure 1). Besides, RDEA427 shows a lower potential for cytochrome P450 induction and improved metabolic properties than RPV. Therefore, it has been undergone preliminary clinical evaluation as a drug candidate. ${ }^{6-8}$

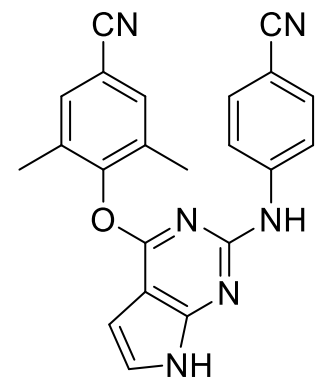

RDEA427 (1)

$\mathrm{EC}_{50}(\mathrm{wt})=0.16 \mathrm{nM}$

$\mathrm{EC}_{50}(\mathrm{Y} 181 \mathrm{C})=4.5 \mathrm{nM}$

$\mathrm{EC}_{50}(\mathrm{Y} 188 \mathrm{~L})=4.0 \mathrm{nM}$

$\mathrm{EC}_{50}(\mathrm{~L} 100 \mathrm{I} / \mathrm{K} 103 \mathrm{~N})=7.8 \mathrm{nM}$

Figure 1. Structure and anti-HIV-1 profiles of RDEA427 (1).

However, only one synthetic route has been disclosed in the literature till now, with a total yield less than $1.9 \%$ (Scheme 1): ${ }^{9}$ the starting material 2,6-diamino-2,3-dihydropyrimidin-4(1H)- one (2) was condensed with chloroacetaldehyde (3) in the presence of $\mathrm{NaOAc}$ in water to provide the intermediate 2-amino-3,7-dihydro-4H-pyrrolo[2,3-d]pyrimidin-4-one (4). Chlorination of 4 in $\mathrm{POCl}_{3}$ using $\mathrm{N}, \mathrm{N}$-dimethylaniline and triethylbenzylammonium chloride (TEBAC) as catalysts afforded 4-chloro-7H-pyrrolo[2,3- $d$ ]pyrimidin-2-amine (5). 5 was first benzyl-protected, and then underwent a nucleophilic reaction with 4-hydroxy-3,5-dimethylbenzonitrile (7) to give intermediate 8. 8 passed through a Schiemann reaction in 60\% HF-pyridine solution to supply the key intermediate 9. At last, 9 underwent another nucleophilic reaction and subsequent deprotection to afford RDEA427 (1). In the above synthesis route of RDEA427, obvious disadvantages exist as follows: 1) the overall yield is extremely low; 2) the route contains conditions under high temperature heating or rather low temperature cooling, which is very energy consuming; 3) the extremely toxic HF-pyridine solution and explosive $t$-butylnitrite were utilized, which was not suitable for large-scale industrialization; 4) silica gel chromatography was employed in the latter six steps to obtain the desired products, which is less environment-friendly and uneconomic for quantity production. Therefore, we became greatly interested in designing a more practical, more environment-friendly synthetic approach with improved total yield. 


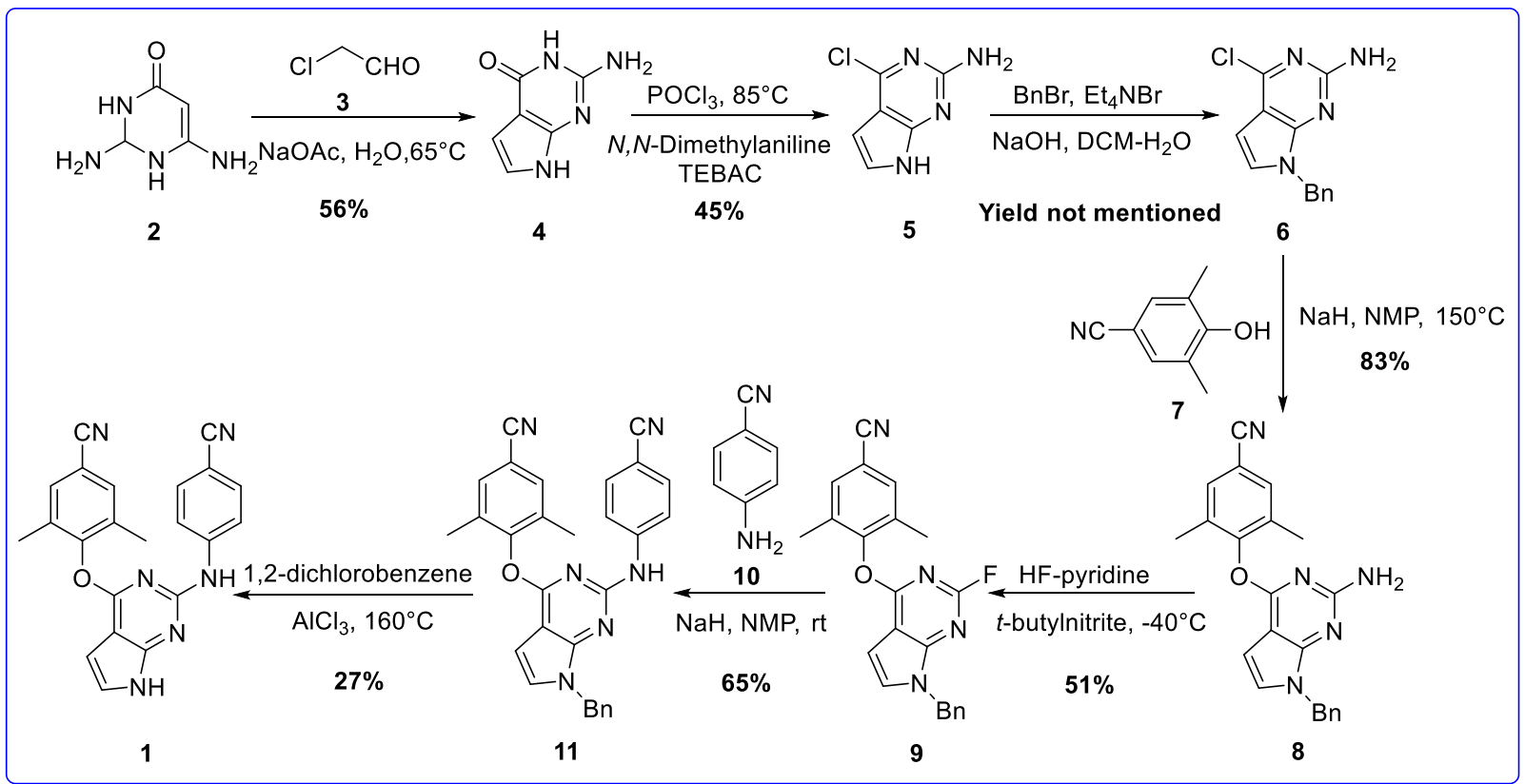

Scheme 1. Discovery route of RDEA427 (1).

\section{Results and Discussion}

The new synthesis of RDEA427 was accomplished by a relatively more environment-friendly approach with good yields (Scheme 2). The synthesis started with the commercially available 2,4dichloro-7H-pyrrolo[2,3- $d$ ]pyrimidine (12), which was first protected by (2(chloromethoxy)ethyl)trimethylsilane (SEM-Cl) to afford 2,4-dichloro-7-((2(trimethylsilyl)ethoxy)methyl)-7H-pyrrolo[2,3-d]pyrimidine (13). Compound 13 subsequently undergone two SNAr reactions, providing the key intermediate 15. The SEM group was then removed to give the desired product RDEA427 (1). The total yield of the new route was found to be $39 \%$, over 20 times better than that of the original route. With the exception of the third step, the reactions conditions were relatively mild. In addition, no extremely toxic or explosive materials were utilized in the optimized route, and the silica gel chromatography was only employed in three steps, which is more economic for quantity production.

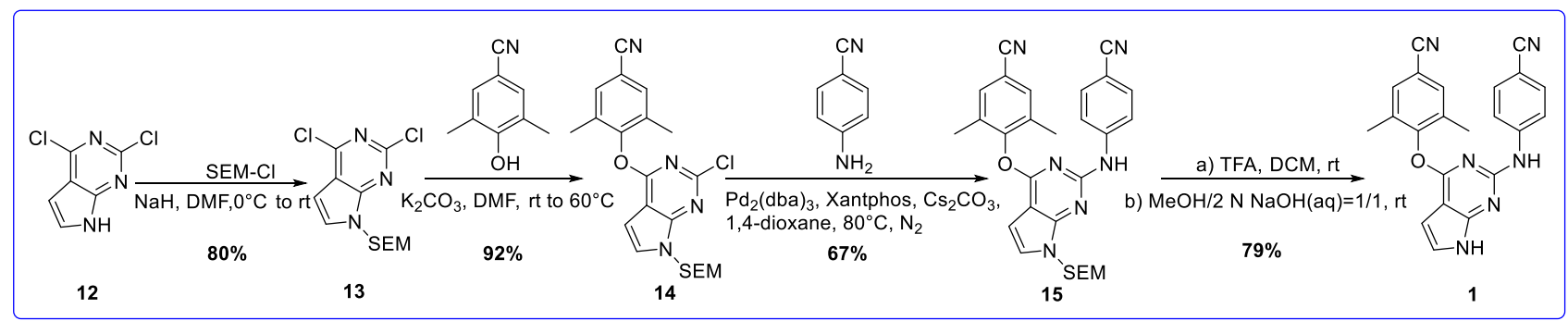

Scheme 2. The improved synthetic route of RDEA427 (1). 
At first, using a protecting-group-free strategy, it was found that the starting material $\mathbf{1 2}$ could not directly afford RDEA427 after two-step SNAr reactions. Subsequently, (Boc) ${ }_{2} \mathrm{O}$ and $p$ toluenesulfonyl chloride $(\mathrm{TsCl})$ were applied as possible protective agents. Unfortunately, both of the designed routes did not work out. Finally, (2-(chloromethoxy)ethyl)trimethylsilane (SEM-Cl) was adopted to achieve the aim.

Moreover, preliminary investigations were carried out to select appropriate Pd catalysts and ligands on the Buchwald-Hartwig reaction, since the third step reaction played a decisive role in improving the overall yield. $\mathrm{Pd}(\mathrm{OAc})_{2} / \mathrm{BINAP}$ and $\mathrm{Pd}_{2}(\mathrm{dba})_{3} / \mathrm{X}$ antphos were used with different stoichiometric ratios, and temperatures were also studied. The reaction conditions and yields were depicted in Table 1. Considering the yield, raw material price and quantity production, the condition using $\mathrm{Pd}_{2}(\mathrm{dba})_{3}(0.015 \mathrm{eq}) / \mathrm{Xantphos}(0.015 \mathrm{eq}) / 80^{\circ} \mathrm{C}$ was ultimately employed.

Table 1. Explorations of Buchwald-Hartwig reaction conditions

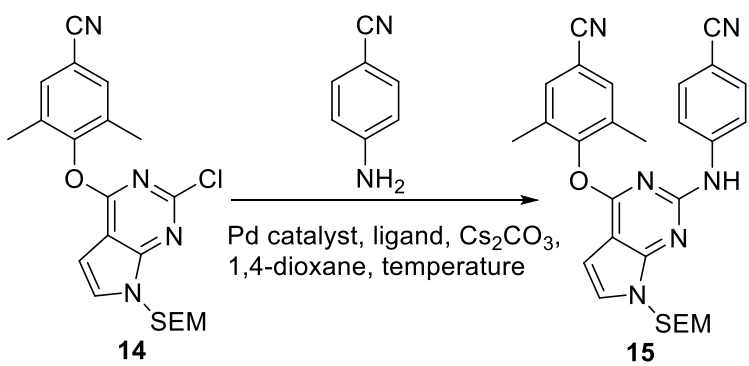

\begin{tabular}{cccccc}
\hline Entry & $\operatorname{Pd}$ catalysts (eq.) & Ligands (eq.) & Temperature $\left({ }^{\circ} \mathrm{C}\right)$ & Time & Yield\% \\
\hline 1 & $\operatorname{Pd}(\mathrm{OAc})_{2}(0.2)$ & $\operatorname{BINAP}(0.4)$ & 150 & $4 \mathrm{~h}$ & 10 \\
2 & $\operatorname{Pd}(\mathrm{OAc})_{2}(0.2)$ & $\operatorname{BINAP}(0.4)$ & 140 & $4 \mathrm{~h}$ & 72 \\
3 & $\mathrm{Pd}(\mathrm{OAc})_{2}(0.2)$ & $\operatorname{BINAP}(0.4)$ & 110 & $4 \mathrm{~h}$ & $0^{\mathrm{a}}$ \\
4 & $\mathrm{Pd}(\mathrm{OAc})_{2}(0.02)$ & $\operatorname{BINAP}(0.04)$ & 140 & $4 \mathrm{~h}$ & 68 \\
5 & $\mathrm{Pd}_{2}(\mathrm{dba})_{3}(0.015)$ & Xantphos $(0.015)$ & 140 & $4 \mathrm{~h}$ & 49 \\
6 & $\operatorname{Pd}_{2}(\mathrm{dba})_{3}(0.015)$ & Xantphos $(0.015)$ & $140(\text { microwave-assisted })^{\mathrm{b}}$ & $1 \mathrm{~h}$ & 50 \\
7 & $\operatorname{Pd}_{2}(\mathrm{dba})_{3}(0.015)$ & Xantphos $(0.015)$ & 110 & $4 \mathrm{~h}$ & 63 \\
8 & $\operatorname{Pd}_{2}(\mathrm{dba})_{3}(0.015)$ & Xantphos $(0.015)$ & 80 & $4 \mathrm{~h}$ & $\mathbf{6 7}$ \\
\hline
\end{tabular}

${ }^{a}$ This reaction condition did not work. ${ }^{\mathrm{b}}$ Conducted on a CEM Discover SP (0-600W) microwave instrument. 


\section{Conclusions}

We have developed a new synthesis approach of the HIV-1 inhibitor RDEA427. The total yield of the optimized route increased to $39 \%$, over 20 times better than that of the original one. Protective reagents and appropriate $\mathrm{Pd}$ catalysts and ligands on the Buchwald-Hartwig reaction were preliminarily explored. Finally, SEM-Cl and $\mathrm{Pd}_{2}(\mathrm{dba})_{3}(0.015 \mathrm{eq}) / \mathrm{Xantphos}(0.015$ eq) were adopted. On the whole, the reaction conditions are relatively mild, and the new route is more environment-friendly and economic, therefore is suitable for quantity production in the future.

\section{Experimental Section}

General. All melting points ( $\mathrm{mp}$ ) were determined on a micromelting point apparatus and are uncorrected. Mass spectra were performed on a LC Autosampler Device: Standard G1313A instrument by electrospray ionization. ${ }^{1} \mathrm{H}$ NMR and ${ }^{13} \mathrm{C}$ NMR spectra were obtained on a Bruker AV-400 spectrometer (Bruker BioSpin, Fällanden, Switzerland) in the indicated solvent DMSO$d_{6}$. Chemical shifts were expressed in $\delta$ units (ppm), using TMS as an internal standard, and $J$ values were reported in hertz $(\mathrm{Hz})$. TLC was performed on Silica Gel GF254. Spots were visualized by irradiation with UV light $(\lambda 254 \mathrm{~nm})$. Flash column chromatography was carried out on columns packed with silica gel 60 (200-300 mesh). Solvents were of reagent grade and, if needed, were purified and dried by standard methods. The key reagents were purchased from commercial suppliers and with no further purification when used. Rotary evaporators were served in concentration of the reaction solutions under reduced pressure.

2,4-Dichloro-7-((2-(trimethylsilyl)ethoxy)methyl)-7H-pyrrolo[2,3- $\boldsymbol{d}]$ pyrimidine (13). To a suspension of $\mathrm{NaH}(60 \%$ in oil, $234 \mathrm{mg}, 5.85 \mathrm{mmol})$ in anhydrous DMF (3 mL) was dropwise added a solution of $12(1.00 \mathrm{~g}, 5.32 \mathrm{mmol})$ in DMF $(5 \mathrm{~mL})$ at $0{ }^{\circ} \mathrm{C}$. Additional DMF $(2 \mathrm{~mL})$ was used to rinse the flask and then was added to the solution. The resulting mixture was stirred for $15 \mathrm{~min}$ and then treated with SEM-Cl $(1 \mathrm{~mL}, 5.85 \mathrm{mmol})$ slowly. After the mixture was stirred at room temperature for $4 \mathrm{~h}$, the reaction was quenched with water $(150 \mathrm{~mL})$, and extracted with EtOAc $(3 \times 40 \mathrm{~mL})$. The organic layers were combined, washed with saturated brine $(50 \mathrm{~mL})$, dried over anhydrous $\mathrm{Na}_{2} \mathrm{SO}_{4}$, filtered and concentrated under reduced pressure. Finally, the residue was further purified by silica gel chromatography with EtOAc/petroleum ether $=1 / 4$ to afford the title compound as a colorless oil (1.35 g). Yield: $80 \% .{ }^{1} \mathrm{H}$ NMR (400 MHz, DMSO- $\left.d_{6}\right)$ $\delta$ : $7.99\left(\mathrm{~d}, J_{\mathrm{HH}} 3.68 \mathrm{~Hz}, 1 \mathrm{H}\right.$, pyrrole-H), $6.82\left(\mathrm{~d}, J_{\mathrm{HH}} 3.68 \mathrm{~Hz}, 1 \mathrm{H}\right.$, pyrrole-H), $5.72\left(\mathrm{~s}, 2 \mathrm{H}, \mathrm{NCH}_{2}\right)$, $3.64\left(\mathrm{~d}, J_{\mathrm{HH}} 8.08 \mathrm{~Hz}, 2 \mathrm{H}, \mathrm{OCH}_{2}\right), 0.94\left(\mathrm{~d}, J_{\mathrm{HH}} 8.08 \mathrm{~Hz}, 2 \mathrm{H}, \mathrm{SiCH}_{2}\right), 0.00\left(\mathrm{~s}, 9 \mathrm{H}, \mathrm{CH}_{3} \times 3\right) .{ }^{13} \mathrm{C} \mathrm{NMR}$ $\left(100 \mathrm{MHz}, \mathrm{DMSO}-d_{6}\right) \delta: 153.26,152.33,151.77,133.38,117.24,100.82,74.17,67.08,18.13$, 0.50. ESI-MS: $m / z 318.2(\mathrm{M}+\mathrm{H})^{+}, \mathrm{C}_{12} \mathrm{H}_{17} \mathrm{Cl}_{2} \mathrm{~N}_{3} \mathrm{OSi}(317.05)$.

4-((2-Chloro-7-((2-(trimethylsilyl)ethoxy)methyl)-7H-pyrrolo[2,3- $d]$ pyrimidin-4-yl)oxy)-3,5dimethylbenzonitrile (14). $\mathrm{K}_{2} \mathrm{CO}_{3}(0.70 \mathrm{~g}, 5.04 \mathrm{mmol})$ was added to a solution of 4-hydroxy-3,5- 
dimethylbenzonitrile $(0.37 \mathrm{~g}, 2.52 \mathrm{mmol})$ in anhydrous DMF $(6 \mathrm{~mL})$. The mixture was stirred at room temperature for $10 \mathrm{~min}$, then intermediate $13(0.80 \mathrm{~g}, 2.52 \mathrm{mmol})$ in DMF (3 mL) was slowly added. The reaction was heated at $60{ }^{\circ} \mathrm{C}$ for $3 \mathrm{~h}$ until its completion. $50 \mathrm{~mL} \mathrm{H} \mathrm{H}_{2} \mathrm{O}$ was added, and the resultant precipitate was filtered, washed with water and dried in vacuo to obtain the crude product $14(1.00 \mathrm{~g})$ as a white solid, which could be used in the next step without further purification. Yield: 92\%, mp 139.5-140.1 ${ }^{\circ} \mathrm{C}$. ESI-MS: $\mathrm{m} / z \quad 429.4(\mathrm{M}+\mathrm{H})^{+}, 451.4(\mathrm{M}+\mathrm{Na})^{+}$, $\mathrm{C}_{21} \mathrm{H}_{25} \mathrm{ClN}_{4} \mathrm{O}_{2} \mathrm{Si}$ (428.14).

4-((2-((4-Cyanophenyl)amino)-7-((2-(trimethylsilyl)ethoxy)methyl)-7H-pyrrolo[2,3-

d]pyrimidin-4-yl)oxy)-3,5-dimethylbenzonitrile (15). A mixture of 14 (1.00 g, $2.34 \mathrm{mmol})$, 4aminobenzonitrile (0.28 g, $2.34 \mathrm{mmol}), \mathrm{Cs}_{2} \mathrm{CO}_{3}(1.14 \mathrm{~g}, 3.51 \mathrm{mmol}), \mathrm{Pd}_{2}(\mathrm{dba})_{3}(32.1 \mathrm{mg}, 0.0351$ $\mathrm{mmol}$ ) and Xantphos $(20.3 \mathrm{mg}, 0.0351 \mathrm{mmol})$ was dissolved in $40 \mathrm{~mL} \mathrm{1,4-dioxane,} \mathrm{and} \mathrm{then} \mathrm{the}$ solution was refluxed at $80^{\circ} \mathrm{C}$ for $4 \mathrm{~h}$ under $\mathrm{N}_{2}$ atmosphere. Subsequently, the solution was filtered and concentrated under reduced pressure. Finally, the residue was further purified by silica gel chromatography with EtOAc/petroleum ether $=1 / 8$ and recrystallized from absolute ethanol to give $15(0.80 \mathrm{~g})$ as a white solid. Yield: $67 \%, \mathrm{mp} 190.0-191.0{ }^{\circ} \mathrm{C} .{ }^{1} \mathrm{H}$ NMR (400 MHz, DMSO- $\left.d_{6}\right) \delta$ : 10.03 (s, 1H, NH), 7.93 (s, 2H, OPh-H), 7.83 (d, J $\left.J_{\mathrm{HH}} 8.72 \mathrm{~Hz}, 2 \mathrm{H}, \mathrm{CN}-\mathrm{Ph}-\mathrm{H}\right), 7.63$ (d, J $J_{\mathrm{HH}} 8.84$ $\mathrm{Hz}, 2 \mathrm{H}, \mathrm{CN}-\mathrm{Ph}-\mathrm{H}), 7.55$ (d, $J_{\mathrm{HH}} 3.64 \mathrm{~Hz}, 1 \mathrm{H}$, pyrrole-H), 6.69 (d, $J_{\mathrm{HH}} 3.60 \mathrm{~Hz}, 1 \mathrm{H}$, pyrrole-H), 5.69 (s, 2H, $\left.\mathrm{NCH}_{2}\right), 3.70\left(\mathrm{~d}, J_{\mathrm{HH}} 8.08 \mathrm{~Hz}, 2 \mathrm{H}, \mathrm{OCH}_{2}\right), 2.27\left(\mathrm{~s}, 6 \mathrm{H}, \mathrm{CH}_{3} \times 2\right), 0.97$ (d, $J_{\mathrm{HH}} 8.08 \mathrm{~Hz}$, $\left.2 \mathrm{H}, \mathrm{SiCH}_{2}\right), 0.00\left(\mathrm{~s}, 9 \mathrm{H}, \mathrm{CH}_{3} \times 3\right) .{ }^{13} \mathrm{C} \mathrm{NMR}\left(100 \mathrm{MHz}, \mathrm{DMSO}-d_{6}\right) \delta: 161.63,155.59,155.20$, 154.77, 146.22, 133.87, 133.74, 133.59, 127.63, 120.64, 119.66, 118.76, 109.57, 102.68, 99.85, 99.79, 73.66, 66.57, 18.11, 16.83, -0.50. ESI-MS: $m / z \quad 511.4(\mathrm{M}+\mathrm{H})^{+}, 533.4(\mathrm{M}+\mathrm{Na})^{+}$, $\mathrm{C}_{28} \mathrm{H}_{30} \mathrm{~N}_{6} \mathrm{O}_{2} \mathrm{Si}(510.22)$.

\section{4-((2-((4-Cyanophenyl)amino)-7H-pyrrolo[2,3-d]pyrimidin-4-yl)oxy)-3,5-}

dimethylbenzonitrile (RDEA427, 1). To a solution of $15(0.50 \mathrm{~g}, 0.98 \mathrm{mmol})$ in dichloromethane $(6 \mathrm{~mL})$ was added $4 \mathrm{~mL}$ trifluoroacetic acid, and then the mixture was stirred at room temperature for $2 \mathrm{~h}$. The extra solvent was removed under reduced pressure to provide a greyish white solid, which was redissolved in methanol/2N NaOH(aq) $(1 / 1,5 \mathrm{~mL})$. The reaction mixture was then stirred at room temperature for $4 \mathrm{~h}$. Water $(100 \mathrm{~mL})$ was added and the solution was extracted using EtOAc $(3 \times 30 \mathrm{~mL})$, washed with saturated brine $(50 \mathrm{~mL})$, dried over anhydrous $\mathrm{Na}_{2} \mathrm{SO}_{4}$, filtered and concentrated under reduced pressure. Futher, the residue was purified by silica gel chromatography with EtOAc/petroleum ether =1/2 and recrystallized from absolute methanol to afford the pure target compound $\mathbf{1}(0.29 \mathrm{~g})$ as a white solid. Yield: $79 \%$, mp: $280.3-282.2{ }^{\circ} \mathrm{C} .{ }^{1} \mathrm{H}$ NMR (400 MHz, DMSO-d $\left.d_{6}\right) \delta: 11.87$ (s, 1H, pyrrole-NH), 9.75 (s, 1H, NH), 7.79 (s, 2H, OPh-H), $7.66\left(\mathrm{~d}, J_{\mathrm{HH}} 8.80 \mathrm{~Hz}, 2 \mathrm{H}, \mathrm{CN}-\mathrm{Ph}-\mathrm{H}\right), 7.49$ (d, $\left.J_{\mathrm{HH}} 8.84 \mathrm{~Hz}, 2 \mathrm{H}, \mathrm{CN}-\mathrm{Ph}-\mathrm{H}\right), 7.25$ (dd, $J_{\mathrm{HH}-1} 3.44 \mathrm{~Hz}$, $J_{\mathrm{HH}-2} 2.32 \mathrm{~Hz}, 1 \mathrm{H}$, pyrrole-H), $6.46\left(\mathrm{dd}, J_{\mathrm{HH}-1} 3.40 \mathrm{~Hz}, J_{\mathrm{HH}-2} 1.76 \mathrm{~Hz}, 1 \mathrm{H}\right.$, pyrrole-H), $2.14(\mathrm{~s}, 6 \mathrm{H}$, $\left.\mathrm{CH}_{3} \times 2\right) .{ }^{13} \mathrm{C}$ NMR $\left(100 \mathrm{MHz}, \mathrm{DMSO}-d_{6}\right) \delta: 160.87,155.29,154.35,154.34,145.88,133.38$, 133.11, 132.98, 123.63, 120.16, 119.13, 117.91, 108.86, 101.74, 99.04, 98.60, 16.31. ESI-MS: $\mathrm{m} / \mathrm{z}$ $379.5(\mathrm{M}-\mathrm{H})^{-}, \mathrm{C}_{22} \mathrm{H}_{16} \mathrm{~N}_{6} \mathrm{O}(380.14)$. 


\section{Acknowledgements}

Financial support from the National Natural Science Foundation of China (NSFC Nos. 81273354, 81573347), Key Project of NSFC for International Cooperation (No. 81420108027), Young Scholars Program of Shandong University (YSPSDU No. 2016WLJH32, to P.Z.), the Science and Technology Development Project of Shandong Province (No. 2014GSF118175, 2014GSF118012) and Major Project of Science and Technology of Shandong Province (No. 2015ZDJS04001) is gratefully acknowledged.

\section{References}

1. Zhan, P.; Pannecouque, C.; De Clercq, E.; Liu, X. J. Med. Chem. 2016, 59, 2849. https://doi.org/10.1021/acs.jmedchem.5b00497

2. Zhan, P.; Chen, X.; Li, D.; Fang, Z.; De Clercq, E.; Liu, X. Med. Res. Rev. 2013, 33, E1. https://doi.org/10.1002/med.20241

3. Huang, B.; Li, C.; Chen, W.; Liu, T.; Yu, M.; Fu, L.; Sun, Y.; Liu, H.; De Clercq, E.; Pannecouque, C.; Balzarini, J.; Zhan, P.; Liu, X. Eur. J. Med. Chem. 2015, 92, 754. https://doi.org/10.1016/j.ejmech.2015.01.042

4. Raney, A.; Hamatake, R.; Xu, W.; Girardet, J.-L.; Vernier, J.-M.; Yeh, L.-T.; Quart, B. 21st International Conference on Antiviral Research, Montreal, Quebec, Canada, 2008.

5. Raney, A.; Hamatake, R.; Xu, W.; Vernier, J.-M.; Girardet, J.-L.; Weingarten, P.; Zhou, D.; Kim, H.K.; Dick, R.; Yeh, L.-T.; Quart, B. 15st Conference on Retroviruses and Opportunistic Infections, Boston, MA, USA, 2008.

6. Tian, Y.; Du, D.; Rai. D.; Wang, L.; Liu, H.; Zhan, P.; De Clercq, E.; Pannecouque, C.; Liu, X. Bioorg. Med. Chem. 2014, 22, 2052. https://doi.org/10.1016/j.bmc.2014.02.029

7. Wang, L.; Tian, Y.; Chen, W.; Liu, H.; Zhan, P.; Li, D.; Liu, H.; De Clercq, E.; Pannecouque, C.; Liu, X. Eur. J. Med. Chem. 2014, 85, 293. https://doi.org/10.1016/i.ejmech.2014.07.104

8. Huang, B.; Liang, X.; Li, C.; Chen, W.; Liu, T.; Li, X.; Sun, Y.; Fu, L.; Liu, H.; De Clercq, E.; Pannecouque, C.; Zhan, P.; Liu, X. Eur. J. Med. Chem. 2015, 93, 330. https://doi.org/10.1016/j.ejmech.2015.02.022

9. Girardet, J.-L.; Koh, Y.; Shaw, S.; Kin, H.K.; WO2006122003A2, 2006. 